\title{
Theobromine Effects on Enamel Surface Microhardness: In Vitro
}

\author{
Grace Syafira, Rina Permatasari, Nina Wardani \\ Department of Conservative Dentistry, Faculty of Dentistry, University of Prof. Dr. Moestopo (B), Jakarta 12250, \\ Indonesia \\ Corresponding e-mail to: rinapermatasari@gmail.com
}

\begin{abstract}
Dental caries is still a dental health problem in Indonesia. Fluoride, one of the dental caries prevention materials but its safety and the danger of fluorosis is still debated. Theobromine is an alkaloid compounds contained in cocoa beans. Theobromine is believed to increase enamel microhardness with mineral changes in the enamel superficial layer. Objectives: To determine the influence of Theobromine on the enamel surface microhardness. Effective dose of theobromine to affect enamel hardness will be determined as well. Methods: This study used 40 premolar tooth crown pieces that were embedded in epoxy resin. Furthermore specimens were randomly divided into 4 groups, which were control (distilled water), theobromine $100 \mathrm{mg} / \mathrm{L}$ (T100), theobromine $500 \mathrm{mg} / \mathrm{L}$ (T500) and theobromine $1000 \mathrm{mg} / \mathrm{L}$ (T1000). The specimens were immersed for 15 minutes and microhardness test was performerd using Knoop microhardness tester. Results: Increasing enamel microhardness was observed after treatment with four different theobromine concentration. The highest increased of enamel microhardness was shown in T1000 group and difference compared to other group were statistically significant $(\mathrm{p}<0.05)$. Conclusion: Theobromine is a potential dental caries prevention material due to its effect in improving the surface microhardness of tooth enamel.
\end{abstract}

\begin{abstract}
ABSTRAK
Efek teobromin terhadap kekerasan mikro permukaan email. Karies gigi masih menjadi masalah kesehatan gigi di Indonesia. Fluor adalah salah satu bahan pencegah karies gigi namun keamanan dan bahaya fluorosis masih diperdebatkan. Teobromin adalah senyawa alkaloid yang terkandung di dalam biji kakao. Teobromin dipercaya dapat meningkatkan kekerasan mikro email dengan terjadinya perubahan mineral pada lapisan permukaan email. Tujuan: Menentukan pengaruh teobromin terhadap kekerasan permukaan email gigi. Dosis efektif teobromin untuk mempengaruhi kekerasan email akan ditetapkan juga. Metode: 40 potongan mahkota gigi premolar ditanam pada resin epoksi. Selanjutnya spesimen dibagi secara random menjadi 4 kelompok, yaitu kontrol (aquadest), teobromin 100mg/L (T100), teobromin 500mg/L (T500), dan teobromin 1000mg/L (T1000). Spesimen direndam selama 15 menit, kemudian diuji kekerasan mikronya dengan menggunakan Knoop microhardness tester. Hasil: Peningkatan kekerasan mikro email terjadi setelah perlakuan dengan empat konsentrasi teobromin yang berbeda. Peningkatan kekerasan mikro email tertinggi terjadi pada kelompok T1000 dan terdapat perbedaan bermakna dibandingkan dengan ketiga kelompok lainnya $(p<0,05)$. Simpulan: Teobromin merupakan bahan pencegah karies gigi yang potensial karena kemampuannya dalam meningkatkan kekerasan permukaan email gigi.
\end{abstract}

Key words: enamel, surface microhardness, theobromine

\section{PENDAHULUAN}

Sampai saat ini karies masih merupakan masalah dalam kesehatan gigi dan mulut di Indonesia dengan data prevalensi karies aktif sebesar 63\%, sehingga pencegahan menjadi penting. ${ }^{1}$ Pencegahan karies gigi dapat dilakukan melalui pengubahan gaya hidup, kebiasaan penyikatan gigi, kontrol diet, perbaikan kualitas saliva, terapi antibakteri, terapi penghambatan proses demineralisasi email serta terapi meng- gunakan biomaterial untuk menghambat proses karies dengan pelapis ceruk dan fisur gigi, atau bahan tambal dari semen ionomer kaca yang mengandung fluor. ${ }^{2,3}$

Demineralisasi email dapat terjadi akibat terjadinya penarikan ion hidroksil $\left(\mathrm{OH}^{-}\right)$dari email gigi karena asam organik hasil proses metabolisme karbohidrat dan mikroorganisme menyebabkan penurunan $\mathrm{pH}$ lingkungan dan peningkatan kadar ion hidrogen $\left(\mathrm{H}^{+}\right)$. Hal ini ditandai dengan kerusakan permukaan dan 
penurunan kekerasan mikro permukaan email. ${ }^{4,5}$ Saat ini fluor masih menjadi bahan utama yang digunakan dalam remineralisasi email gigi, namun terdapat risiko fluorosis apabila diberikan dalam jumlah yang berlebihan. Hasil penelitian yang dilakukan oleh National Health and Medical Research Center, Melbourne dan The International Society for Fluoride Research, menyimpulkan bahwa perlu dilakukan penelitian lebih lanjut tentang fluoridasi. Penelitian yang dianjurkan khususnya mengenai keamanan dosis yang berperan sebagai penyebab terjadinya fluorosis. ${ }^{6-8}$

Sumber mineral utama untuk proses remineralisasi email secara alamiah adalah kalsium dan fosfat dari saliva pada kondisi jenuh. ${ }^{9}$ Remineralisasi email sudah diteliti sejak 100 tahun yang lalu dan diusulkan menjadi perawatan lesi karies dini secara non invasif. ${ }^{10}$ Sejak 50 tahun silam, fluor dinyatakan berperan dalam menghambat proses karies dengan cara menghambat proses demineralisasi dan meningkatkan proses remineralisasi melalui pembentukan fluoroapatit dan kalsium florida, serta penghambatan kerja enzim bakteri melalui aktivitas antimikrobial., ${ }^{911-13}$ Konsensus terbaru menyatakan bahwa fluor tidak lagi digunakan secara sistemik yaitu dengan mengubah struktur email sebelum erupsi gigi, melainkan secara lokal yaitu kontak langsung dengan permukaan email gigi. ${ }^{14}$ Selain fluor, saat ini telah terdapat tiga bahan remineralisasi yaitu casein phosphopeptide stabilized amorphous calcium phosphate (CPP-ACP), unstabilized amorphous calcium phosphate (ACP), dan bioactive glass containing calcium sodium phosphosilicate. Ketiga bahan tersebut mengandalkan kalsium dan fosfat untuk meningkatkan kemampuan saliva dalam meremineralisasi kehilangan mineral pada email. Namun bukti klinis yang mendukung mekanisme tersebut masih belum banyak dilaporkan. ${ }^{9}$

Teobromin adalah senyawa alkaloid golongan metilxantina yang terdapat secara alami pada biji kakao atau cokelat (Theobroma cacao). Teobromin terdapat di dalam cokelat pekat, enam hingga tujuh kali lipat lebih banyak dibanding kafein. Kafein merupakan stimultan sistem saraf pusat, sedangkan teobromin hampir tidak memiliki efek tersebut. ${ }^{15}$

Beberapa tahun terakhir teobromin mulai diteliti untuk dimanfaatkan bagi kesehatan gigi. Teobromin yang terkandung dalam cokelat bubuk ternyata memiliki efek antikariogenik yang lebih tinggi dibanding fluor dalam mengurangi kelarutan email setelah paparan asam fosfat. ${ }^{16}$ Kekerasan permukaan email gigi berhubungan dengan pertukaran mineral pada lapisan permukaan email dan teobromin $200 \mathrm{mg} / \mathrm{L}$ memiliki efek positif pada remineralisasi email. ${ }^{17}$ Hasil ini diperkuat dengan penelitian berikutnya yang menyimpulkan bahwa teobromin dari tanaman kakao dapat memberikan proteksi yang sangat hebat pada permukaan email gigi. ${ }^{18}$ Sebuah penelitian in vitro menunjukkan efektivitas teobromin terhadap kekerasan permukaan email dan proses remineralisasi sama dengan gel Acidulated Phosphate Fluoride (APF) serta krim CCP-ACP. ${ }^{19}$

Berdasarkan hal tersebut, penelitian in vitro ini dilakukan untuk mengetahui manfaat teobromin terhadap kesehatan gigi ditinjau dari pengaruhnya dalam meningkatkan kekerasan email gigi. Data penelitian ini akan memberikan sumbangan kebaharuan tentang material untuk remineralisasi.

\section{METODE}

Pembuatan spesimen dilakukan di laboratorium preklinik, Fakultas Kedokteran Gigi Universitas Prof. Dr. Moestopo (Beragama). Pengukuran kekerasan permukaan email dilakukan di laboratorium material kedokteran gigi, Fakultas Kedokteran Gigi Universitas Indonesia.

Sebanyak 20 gigi premolar bebas karies yang baru saja diekstraksi, dipisahkan mahkota dari akarnya dengan menggunakan bur carborandom disc berkecepatan rendah. Mahkota gigi kemudian dibelah dari arah koronal ke apikal pada pertengahan sisi bukal dan palatal, hingga didapatkan dua pemukaan email yaitu bukal dan lingual. Semua mahkota gigi dibersihkan dari jaringan yang menempel menggunakan $\mathrm{NaOCl}$ $2,5 \%$ dilanjutkan dengan alkohol $70 \%$, dibersihkan dengan alat pembersih ultrasonik (Cole-Palmer 8891), dan direndam dalam larutan salin sampai saat percobaan.

Sebanyak 40 potongan mahkota gigi dipersiapkan untuk difiksasi dengan cara ditanam pada resin epoksi sebelum pengujian kekerasan permukaan. Permukaan email yang paling rata dilekatkan dengan stiker yang diletakkan pada tatakan kaca, dilanjutkan dengan peletakkan cincin pipa paralon sebagai cetakan. Resin epoksi cair yang sudah dicampur katalis diaduk dengan cepat dan segera dituang ke dalam cetakan. Setelah keras, stiker dan cetakan dilepas dari resin, dan spesimen permukaan email siap diasah dan dipoles dengan Grinding/polishing machine merek Steuers LaboPol-21. Kertas amplas 2000 grit, pasta poles merek DiaPro dan kain poles digunakan, sehingga didapatkan 40 permukaan email yang cukup luas, rata, dan halus. Grinding dan polishing yang dilakukan tidak mengambil lebih dari $0,5 \mathrm{~mm}$ tebal email.

Bubuk teobromin (Sigma, USA) dilarutkan dengan dapar karbonat $\mathrm{pH}$ 9,6 dan aquadest hingga didapatkan tiga konsentrasi yaitu larutan teobromin $100 \mathrm{mg} / \mathrm{L}$ (T100), 500mg/L (T500), dan 1000mg/L (T1000). Selanjutnya 40 spesimen dibagi secara acak dalam empat kelompok, yaitu kontrol (aquadest), T100, T500, dan T1000, sehingga setiap kelompok terdiri dari 10 spesimen. Spesimen kemudian direndam dalam larutan teobromin selama 15 menit (Gambar 1). Permukaan 
email setiap spesimen kemudian siap diuji kekerasannya menggunakan knoop micro hardness tester (Shimadzu HMV2) (Gambar 2).

Uji kekerasan permukaan dilakukan menggunakan indenter knoop dengan beban $100 \mathrm{gr} / 980,7 \mathrm{mN}$, selama 10 detik dengan tiga kali penjejasan pada setiap spesimen. Hasil pengujian memiliki nilai satuan KHN dengan merujuk nilai rata-rata email normal adalah antara $314-361 \mathrm{KHN}^{20}$

\section{HASIL}

Berdasarkan pengamatan pada 40 spesimen, kekerasan permukaan email dari kelompok kontrol tanpa perlakuan dan dengan perlakuan T100, T500, serta T1000 yang diuji dan diukur dengan knoop micro hardness tester, diperoleh data seperti yang terlihat pada Tabel 1 dan Gambar 3. Terlihat adanya peningkatan kekerasan email pada kelompok T100, T500, dan T1000 dibandingkan kontrol. Peningkatan kekerasan email tertinggi terlihat pada kelompok T1000, dengan peningkatan sebesar $1,3 \%$ dibanding kontrol $(p<0,05)$. Berdasarkan analisis statistik dengan uji ANOVA satu arah, perbedaan tersebut ternyata bermakna dengan nilai $p=0,0001$, setelah sebelumnya dilakukan uji normalitas dan homogenitas data yang hasilnya normal dan homogen, sehingga perhitungan statistik bisa dilakukan secara parametrik.

Tabel 2 memperlihatkan perbedaan yang lebih jelas diantara kelompok dari hasil perhitungan uji post hoc. Terlihat tidak ada perbedaan bermakna antara nilai KHN kelompok kontrol dengan T100 $(p=0,327)$, demikian pula antara kelompok T100 dan T500 ( $p=0,648)$. Namun perbedaan yang bermakna ternyata terlihat antara nilai KHN kelompok kontrol dengan T500 $(p=0,031)$ maupun T1000 ( $p=0,0001)$, T100 dengan T1000 $(p=0,001)$, dan T500 dengan T1000 ( $p=0,017)$.

\section{PEMBAHASAN}

Penelitian ini bertujuan untuk menganalisis pengaruh teobromin terhadap kekerasan permukaan email. Fluor efektif dalam memperkuat permukaan email gigi dari serangan asam penyebab demineralisasi email, namun keamanan tentang penggunaan fluor masih diperdebatkan. Teobromin yang merupakan senyawa alkaloid berasal dari ekstraksi biji cokelat, dilaporkan memiliki kemampuan untuk memperkuat email gigi. ${ }^{19}$ Namun kehadiran teobronomin di dalam produk olahan cokelat sebagian besar telah bercampur dengan gula, sehingga merupakan kontradiksi terhadap kemampuan untuk memperkuat email. Khasiat bahan-bahan alam seperti juga cokelat, tengah ramai dibicarakan dan cukup banyak menjadi target penelitian. Demikian halnya di bidang kedokteran
Tabel 1. Nilai kekerasan permukaan email kelompok kontrol, T100, T500, T1000 dalam satuan KHN

\begin{tabular}{ccccc}
\hline $\begin{array}{c}\text { Kadar } \\
\text { teobromin }\end{array}$ & n & Rerata \pm SB & Min-Maks & $\boldsymbol{p}$ \\
\hline Kontrol (0) & 10 & $316,30 \pm 42,427$ & $229-365$ & $0,0001^{*}$ \\
T-100 & 10 & $340,70 \pm 35,867$ & $266-384$ & \\
T-500 & 10 & $357,30 \pm 26,462$ & $315-387$ & \\
T-1000 & 10 & $401,90 \pm 14,963$ & $385-423$ & \\
\hline
\end{tabular}

$\mathrm{SB}=$ simpang baku, *perbedaan bermakna $p<0,05$

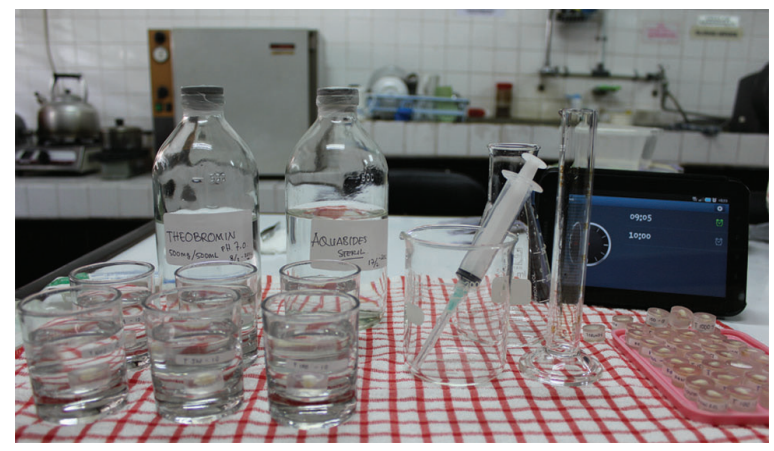

Gambar 1. Perendaman sampel dalam larutan teobromin

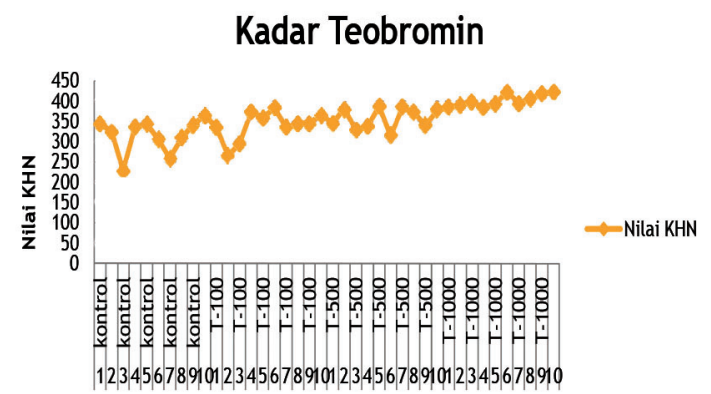

Gambar 2. Perbedaan nilai KHN empat kelompok percobaan. Terlihat rerata nilai KHN yang makin meningkat dari kelompok kontrol hingga T1000

Tabel 2. Perbedaan nilai kekerasan permukaan email antar kelompok setelah dilakukan uji post hoc

\begin{tabular}{|c|c|c|c|c|}
\hline $\begin{array}{c}\text { Kadar } \\
\text { teobromin }\end{array}$ & $\mathbf{n}$ & Rerata \pm SB & Min-Max & $p$ \\
\hline Kontrol & 10 & $316,30 \pm 42,427$ & $229-365$ & 0,327 \\
\hline $\mathrm{T}-100$ & 10 & $340,70 \pm 35,867$ & $266-384$ & \\
\hline Kontrol & 10 & $316,30 \pm 42,427$ & $229-365$ & $0,031 *$ \\
\hline $\mathrm{T}-500$ & 10 & $357,30 \pm 26,462$ & $315-387$ & \\
\hline Kontrol & 10 & $316,30 \pm 42,427$ & $229-365$ & $0,0001^{*}$ \\
\hline $\mathrm{T}-1000$ & 10 & $401,90 \pm 14,963$ & $385-423$ & \\
\hline $\mathrm{T}-100$ & 10 & $340,70 \pm 35,867$ & $266-384$ & 0,648 \\
\hline $\mathrm{T}-500$ & 10 & $357,30 \pm 26,462$ & $315-387$ & \\
\hline $\mathrm{T}-100$ & 10 & $340,70 \pm 35,867$ & $266-384$ & 0,001 \\
\hline $\mathrm{T}-1000$ & 10 & $401,90 \pm 14,963$ & $385-423$ & \\
\hline $\mathrm{T}-500$ & 10 & $357,30 \pm 26,462$ & $315-387$ & 0,017 \\
\hline $\mathrm{T}-1000$ & 10 & $401,90 \pm 14,963$ & $385-423$ & \\
\hline
\end{tabular}

$\mathrm{SB}=$ simpang baku, *perbedaan bermakna $p<0,05$ 
gigi, penelitian sedang banyak mengarah pada pemanfaatan bahan alam untuk meningkatkan kesehatan gigi dan mulut. Tren intervensi minimal juga menjadi topik hangat diperbincangkan di bidang kedokteran gigi. Pencegahan demineralisasi email akibat asam menjadi bagian terpenting dalam usaha pencegahan penyakit karies gigi. Pada penelitian ini teobromin diaplikasikan langsung pada permukaan email gigi premolar bebas karies.

Variasi konsentrasi teobromin yang digunakan di dalam penelitian yaitu $100 \mathrm{mg} / \mathrm{L}, 500 \mathrm{mg} / \mathrm{L}$, dan $1000 \mathrm{mg} / \mathrm{L}$ aquadest dirasakan masih sangat kurang untuk menetapkan dosis efektif teobromin paling tepat terhadap email gigi. Waktu 15 menit digunakan berdasarkan arah penggunaan teobromin sebagai bahan untuk diaplikasikan secara topikal oleh profesional gigi sebagai tindakan pencegahan karies gigi.

Kekerasan permukaan email dianalisis dengan Knoop microhardness tester. Alat ini dipilih berdasarkan kekerapannya digunakan untuk menentukan kekerasan permukaan email pada banyak penelitian. Semakin besar nilai KHN yang dihasilkan, semakin keras permukaan email. Hasil penelitian ini menunjukkan terdapat perbedaan nilai rerata KHN antara kelompok kontrol tanpa perlakuan teobromin dengan tiga kelompok perlakuan. Namun secara statistik, perbedaan bermakna hanya terlihat antara kelompok kontrol dengan T500 dan kontrol dengan T1000. Tidak terlihat perbedaan yang bermakna antara kelompok kontrol dengan T100. Hal ini mengindi-kasikan bahwa konsentrasi teobromin $100 \mathrm{mg} / \mathrm{L}$ tidak seefektif konsentrasi 500 dan 1000mg/L dalam meningkatkan kekerasan permukaan email. Rerata nilai KHN pada kelompok T100 dan T500 dapat meningkatkan KHN yaitu 340,7 dan 357,3, namun ternyata tidak berbeda bermakna secara statistik. Perbedaan nilai rerata KHN antara kelompok T1000 dengan tiga kelompok lain sangat terlihat jelas baik secara substansi maupun secara statistik. Penelitian ini dapat menyimpulkan bahwa konsentrasi $1000 \mathrm{mg} / \mathrm{L}$ merupakan dosis teobromin yang paling efektif dalam meningkatkan kekerasan permukaan email.

Pada penelitian selanjutnya diperlukan lebih banyak variasi dosis teobromin dan waktu pemaparan dalam penelitian lebih lanjut, mengingat pentingnya pertimbangan dosis terendah atau paling efektif dengan waktu tercepat atau paling efisien untuk hasil paling maksimal. Perlu diketahui sumber teobromin terbaik untuk dimanfaatkan dalam meningkatkan kekerasan email gigi, mekanisme kerja teobromin dalam meningkatkan kekerasan email baik di permu-kaan maupun di bawah permukaan, serta perlunya melibatkan saliva, maupun kondisi penurunan $\mathrm{pH}$ akibat adanya asam, sehingga dapat mensimulasikan proses remineralisasi dan remineralisasi yang lebih mirip keadaan klinis sesungguhnya.

\section{SIMPULAN}

Penelitian ini menunjukkan bahwa teobromin dapat meningkatkan kekerasan permukaan email gigi. Konsentrasi teobromin yang paling efektif dalam meningkatkan kekerasan email adalah $1000 \mathrm{mg} / \mathrm{L}$ dengan waktu pemaparan 15 menit.

\section{DAFTAR PUSTAKA}

1. Departemen Kesehatan Republik Indonesia. Profil kesehatan Indonesia 2001. Jakarta. 2002. Indonesian.

2. Featherstone JDB. The caries balance: contributing factors and early detection. J Calif Dent Assoc. 2003;32:129-33.

3. Featherstone JDB, Adair SM, Anderson MH, Berkowitz Rj, Bird WF, Crall JJ, et al. Caries management by risk assessment: consensus statement. J Calif Dent Assoc. 2003;31:257-69.

4. Axelsson JE. An introduction to risk prediction and preventive dentistry. Illinois: Quintessence, 1999.

5. Fejerskov O, Kidd EAM. Dental caries, diseases and it's clinical management. Munksgaard: Blackwell, 2003.

6. Centre for Disease Control and Prevention. Recommendations for using fluoride to prevent and control dental caries in the United States. Atlanta, 2001. [Cited 2012 Jan 5]. Available from: http://www. cdc.gov/mmwr/preview/mmwrhtml/rr5014a1.htm

7. National Health and Medical Research Centre. Review of water fluoridation and fluoride intake from discretionary fluoride supplements. Melbourne, 1999. [Cited 2012 Jan 5]. Available from: http:// www.nhmrc.gov.au/files_nhmrc/publications/ attachments/eh41_1.pdf

8. Adamowicz-Klepalska B, Krzyzagorska J, Emerich-Poplatek K. Fluoride in the environment and oral health in children. The International Society for Fluoride Research. Special Supplement Abstracts of Papers To Be Presented At The XXIIIrd Conference Szczecin. Poland. Fluoride. 2000;33:S1-S39.

9. Cury JA, Tenuta LMA. Enamel remineralization: controlling the caries disease or treating early caries lesions? Braz Oral Res. 2009;23:23-30.

10. Reynolds EC. Calcium phosphate-based remineralization systems: scientific evidence? Aust Dent J. 2008;53:268-73.

11. Torgay BY, Ölmez S, Çelik H, Çehreli Z. In vivo evaluation of effect fluoride varnish on bacterial colonization of tooth enamel using scanning electron microscopy. JIAS. 1994;7:49-55.

12. Kirkham J, Robinson C, Strong M, Shore RC. Effect of frequency and duration of acid exposure on demineralization/remineralization behavior of 
human enamel In vitro. Caries Res. 1994;28:9-13.

13. Pearce EIF, Coole GE, Larsen MJ. The distribution of fluoride in carious human enamel. J Dent Res. 1995;11:1775-62.

14. Cury JA, Tenuta LMA. How to maintain a cariostatic fluoride concentration in the oral environment. Adv Dent Res. 2008;20(1):13-6.

15. Apgar JL, Tarka, SM. Methylxanthines. In I. Knight (Ed.), Chocolate and cocoa: health and nutrition. Oxford, England: Blackwell Science, 1999.

16. Sadeghpour A. A neural network analysis of theobromine vs. fluoride on the enamel surface of human teeth: An experimental case study with strong implications for the production of a new line of revolutionary and natural non-fluoride based dentifrices. Dissertation Abstracts International. 2007;68:B150.
17. Kargul B, Özcan M, Peker S, Nakamoto T, Simmon WB, Falster AU. Effect of theobromine on enamel surface hardness: An in vitro study. The Preliminary Program for IADR General Session. 2010.

18. Kargul B, Ozcan M, Peker S, Nakamoto T, Simmons WB, Falster AU. Evaluation of human surfaces treated with theobromine: A pilot study. Oral Health Prev Dent. 2012;10:275-82.

19. Kargul B, Nakamoto T, Simmon WB, Falster AU. Remineralization potential of theobromine, APF Gel, and CCP-ACP: Pilot study. The Preliminary Program for IADR General Session. 2012.

20. Jennett E, Motamedi M, Rastegar S, Frederickson C, Arcoria C, Powers JM. Dye-enhanced ablation of enamel by pulsed lasers. J Dent Res. 1994;73:1841-7. 